\title{
Pulsing versus constant supply of nutrients $(N, P$ and Si): effect on phytoplankton, mesozooplankton and vertical flux of biogenic matter*
}

\author{
CAMILLA SVENSEN ${ }^{1}$, JENS C. NEJSTGAARD², JORUN K. EGGE ${ }^{2}$ \\ and PAUL WASSMANN ${ }^{1}$
}

\footnotetext{
${ }^{1}$ Norwegian College of Fishery Science, University of Troms $\varnothing$, N-9037 Troms $\varnothing$, Norway. E-mail: camillas@nfh.uit.no

${ }^{2}$ Department of Fisheries and Marine Biology, University of Bergen, HIB, POB 7800, N-5020 Bergen, Norway.
}

\begin{abstract}
SUMMARY: An experiment with eight vertically stratified seawater enclosures of $27 \mathrm{~m}^{3}$ (depth $9.3 \mathrm{~m}$, diameter $2 \mathrm{~m}, 90 \%$ penetration of PAR) was run in order to test whether pulsed addition of nutrients may cause: 1, higher primary production; 2, higher build-up of phytoplankton biomass; 3, larger temporal mismatch between herbivores and phytoplankton biomass; and 4 , higher sedimentation rates, distinguishing in each case between silicate and non-silicate fertilised systems. Nitrate and phosphate were added to all enclosures (NP), while silicate was added to four of the enclosures (NPS). Each enclosure received the same total amount of nutrients, but the nutrients were supplied at four different intervals ranging from one single load to continuous additions. Spring bloom-like systems developed where nutrients were added in one or two pulses as they were characterised by high primary production, high suspended biomass of chlorophyll $a(\mathrm{Chl} a)$ and particulate organic carbon (POC) and high sedimentation rates. In contrast, the seawater enclosures receiving nutrients about every third day or in a continuous supply resembled regenerated systems with low concentrations of suspended Chl $a$ and POC and with low and stable loss rates. Due to a typical autumn inoculum with dominance of dinoflagellates and flagellates, diatoms did not dominate the NPS enclosures. The only significant effect of the silicate addition was higher vertical flux of particulate organic nitrogen in the NPS enclosures, and higher microzooplankton biomass. The mesozooplankton did not show responses to the different frequencies of nutrient additions. However, accumulation of mesozooplankton biomass was higher in the NP-mesocosms, probably reflecting better feeding conditions. We conclude that the frequency of nutrient additions had a stronger influence on the development of the phytoplankton and vertical flux of carbon than the $+/$ - silicate treatment in this experiment.
\end{abstract}

Key words: nutrient pulsing, new and regenerated production, Gyrodinium aureolum, sedimentation, mesocosm.

RESUMEN: SUPLEMENTOS CONSTANTES VS PULSOS DE NUTRIENTES (N, P y SI): EFECTO SOBRE EL FITOPLANCTON, MESOZOOPLANCTON Y EN EL FLUJO DE MATERIA BIOGÉNICA. - Se realizó un experimento en agua de mar verticalmente estratificada y confinada en ocho mesocosmos de $27 \mathrm{~m}^{3}$ (9.3 m de profundidad, $2 \mathrm{~m}$ de diámetro, $90 \%$ de penetración de luz), con el fín de comprobar si la adición de pulsos de nutrientes puede causar: 1. Un incremento de la producción primaria, 2. Un incremento en la biomasa de fitoplancton, 3. Aumento temporal de la desincronización entre los hervíboros y la biomasa de fitoplancton. 4. Aumento de la tasa de sedimentación y si la respuesta de 1-4 puede ser distinta en sistemas fertilizados con y sin silicato. A todos los mesocosmos se añadía nitrato y fosfato (NP), mientras que el silicato solo se añadió a cuatro de los mesocosmos (NPS). Cada mesocosmo recibía la misma cantidad total de nutrientes, pero los nutrientes eran administrados en 4 intervalos diferentes, variando desde una única adición a adiciones en continuo. En los mesocosmos donde los nutrientes se habían añadido en uno o dos pulsos se desarrollaba una proliferación algal semejante a la de primavera, caracterizado por una elevada producción primaria, una elevada biomasa suspendida de clorofila a (chl a) y carbono orgánico particulado (POC) y una elevada tasa de sedimentación. En cambio los mesocosmos que recibían nutrientes una vez cada tres días

*Received June 14, 2001. Accepted November 26, 2001. 
o en adiciones continuadas, se comportaban como sistemas regenerados con bajas concentraciones de Chl a y POC suspendidos y bajas y estables tasas de pérdidas. Debido a un inóculo típico de otoño con dominancia de dinoflagelados y flagelados, las diatomeas no dominaban los mesocosmos NPS. El único efecto significativo de las adiciones de silicato era el de incrementar el flujo vertical de nitrógeno orgánico en los mesocosmos NPS y aumentar la biomasa de microzooplancton. El mesozooplancton no mostraba ninguna respuesta a las diferentes frecuencias de adición de nutrientes. Sin embargo, la acumulación de biomasa de mesozooplancton era más elevada en los NP-mesocosmos, probablemente reflejando mejores condiciones de alimentación. Concluimos que la frecuencia en la adición de nutrientes tenía una influencia más acusada en el desarrollo del fitoplancton y del flujo vertical de carbono que la adición o no adición de silicato en este experimento.

Palabras clave: pulsos de nutrientes, producción nueva y regenerada, Gyrodinium aureolum, sedimentación, mesocosmos.

\section{INTRODUCTION}

The relationship between pelagic productivity and sedimentation of organic matter is complex. Generally high sedimentation rates have been associated with areas or periods with high new production, like spring blooms and upwelling systems (Peinert et al., 1989). Wassmann (1990) suggested a positive, curvilinear relationship between total primary production and sedimentation based on the knowledge that new production systems are usually dominated by autotrophs and simple food web interactions. Consequently, the export potential of the bloom and the pelagic-benthic coupling over lengthy periods of time is determined by the availability of allochthonous, inorganic nutrients. Not only are the amount and ratio of macronutrients important for the coupling between primary production and export ratio, but also the time span(s) through which new nutrients are available (constant or at regular/irregular intervals) may be important. Theory predicts that coexistence of several phytoplankton species is more likely in variable, perturbed environments (Richerson et al., 1970; Sommer, 1984), causing shifts in community composition. Nutrient pulsing may affect growth rates of individual phytoplankton species. Depending on the strength of the nutrient pulse, the responses may also be further influenced and buffered by the grazer community (Cottingham and Schindler, 2000). In order to understand the ecology of different systems and the regulation of biogenic fluxes, it is important to understand responses to perturbations. However, the effect of nutrient pulsing on the vertical flux of biogenic matter has hardly been studied. Most of the experiments including nutrient pulsing are conducted within a single trophic level (phytoplankton), and vertical flux is only rarely investigated experimentally (but see Heiskanen et al., 1996; Svensen et al., 2001).

By adding the same amount of macronutrients, nitrate, phosphate and silicate, to mesocosm enclosures at different time-intervals, we intended to generate systems resembling a) spring bloom-like conditions, b) more regenerative-like systems with continuous supply of nutrients and c) systems with nutrient pulsing. The systems with variable nutrient pulses may mimic pulses of eutrophication. We were also interested in possible ecological changes caused by the availability of silicate, such as shifts in species composition and the consequence for sedimentation. Finally, by monitoring the development of all naturally occurring zooplankton (no filtration of the intake water), we also investigated the potential match and mismatch between phyto- and zooplankton (sensu Reigstad et al., 2000) in our variable "new and regenerated systems". We tested whether pulsed addition of nutrients cause: 1 . higher primary production, 2 . higher build-up of phytoplankton biomass, 3. larger temporal mismatch between herbivores and phytoplankton biomass, and 4. higher sedimentation rates, distinguishing in each case between silicate and non-silicate fertilised systems.

\section{MATERIALS AND METHOD}

\section{Treatments}

The experiments were run on 11-29 August 1998, in Raunefjorden outside Bergen, Norway. For a description of the mesocosm design and location, see Svensen et al. (2001). There was no connection between the water inside the enclosures and the surrounding sea as was the case in Svensen et al. (2001). Eight $27 \mathrm{~m}^{3}$ transparent (90\% penetration of PAR) polyethylene enclosures were filled in situ by pumping unfiltered water from 2-6 m depth outside the mesocosms. A pycnocline was created at approximately $4 \mathrm{~m}$ depth by adding ca $0.6 \mathrm{~m}^{3}$ freshwater to the upper layer, followed by mixing from the airlift-system pumping at a rate of $401 \mathrm{~min}^{-1}$ (Jacobsen et al., 1995).

After stratification was established, all mesocosms were fertilised with nitrate and phosphate (i.e. 
NP enclosures termed NP1, NP2, NP3 and NP4) corresponding to concentrations of $15 \mu \mathrm{M}$ and $1 \mu \mathrm{M}$ respectively. Four of the enclosures received silicate corresponding to $10 \mu \mathrm{M}$ in addition, and will be commonly termed NPS enclosures (consisting of enclosures NPS1, NPS2, NPS3 and NPS4). Nitrate, phosphate and silicate were added to the upper $4 \mathrm{~m}$ (volume $12.5 \mathrm{~m}^{3}$ ) of the enclosures from stock solutions of $\mathrm{NaNO}_{3}, \mathrm{KH}_{2} \mathrm{PO}_{4}$ and $\mathrm{Na}_{2} \mathrm{SiO}_{3} * 5 \mathrm{H}_{2} \mathrm{O}$ (total loads of $16 \mathrm{~g}, 1.7 \mathrm{~g}$ and $26 \mathrm{~g}$ respectively). Integrated over the whole experimental period (19 days), all enclosures received the same amount of $\mathrm{N}$ and $\mathrm{P}$, and all NPS enclosures received the same load of Si. However, the nutrient addition frequency differed between once (enclosures NP-1 and NPS-1), twice (NP-2 and NPS-2), every third day (NP-3 and NPS3 ) and continuous supply (NP-4 and NPS-4). In the latter case, the nutrients dripped into the enclosures from a small container mounted above the enclosures (NP-4 and NPS-4). When the frequency of nutrient pulsing is addressed irrespective of whether they received $\mathrm{N}, \mathrm{P}$ or $\mathrm{Si}$, the enclosures will be termed according to the frequency of pulsing (i.e. simply enclosures $1,2,3$ or 4 ).

\section{Sampling procedures, analyses and calculations}

The first sampling from the mesocosms was performed on August 11 prior to nutrient additions, and thereafter at three-day intervals. Water samples were collected from 2 and $6 \mathrm{~m}$ with 1.51 Ruttner bottles, and were analysed for chlorophyll $a(\mathrm{Chl} a)$, phaeopigments, particulate organic carbon and nitrogen (POC and PON) and nutrients. Chl $a$ samples were filtered onto Satorious filters $(0.45 \mu \mathrm{m})$ and analysed according to Parsons et al. (1984). POC and PON samples were filtered onto pre-combusted Whatman GF/F glass-fibre filters and analysed on a Leeman Lab CEC 440 elemental analyser after removal of carbonate with fumes of concentrated $\mathrm{HCl}$. Primary production was measured using the ${ }^{14} \mathrm{C}$ method according to Steemann Nielsen (1952) and Gargas (1975).

Integration of POC and Chl $a$ were calculated assuming that the sample from $2 \mathrm{~m}$ was representative for the interval 0-4 m, and the sample from $6 \mathrm{~m}$ was representative for the 4-8 $\mathrm{m}$ depth interval.

Sedimented matter was collected in non-poisoned cylindrical sediment traps immersed to $8 \mathrm{~m}$ depth for approximately $24 \mathrm{~h}$. Triplicate subsamples from the settled material were analysed for Chl $a$, POC and PON following the same procedures as for the suspended material. Sedimentation rates $(\mathrm{S}, \mathrm{mg}$ $\mathrm{m}^{-2} \mathrm{~d}^{-1}$ ) of Chl $a$ and POC were calculated according to the equation:

$$
\mathrm{S}=(\mathrm{C} * \mathrm{~V} * \mathrm{~A} / \mathrm{t}) / 1000
$$

where $\mathrm{C}$ is the concentration of $\mathrm{Chl} a$ or POC in the analysed sample $\left(\mathrm{mg} \mathrm{m}^{-3}\right), \mathrm{V}$ is the total volume of the sample, divided by the volume filtered, $\mathrm{A}$ is 1/opening of the sediment trap cylinder $\left(\mathrm{m}^{-2}\right)$ and $\mathrm{t}$ is duration of sediment trap deployment (d).

Sub-samples of $100 \mathrm{ml}$ were collected for enumeration and identification of phytoplankton at 2 $\mathrm{m}$ depth and from the sediment traps. Phytoplankton samples were preserved with a mixture of glutaraldehyde-Lugol solution (Rousseau et al., 1990) (2\% final concentration), and were counted using a light microscope according to a combination of methods as described by Ratkova et al. (1999). Biovolumes of individual cells were calculated from linear dimensions of measured cells applied to appropriate stereometric formulae (Smayda, 1978). Cell volumes were converted to phytoplankton carbon (PPC) according to Strathmann (1967). No distinction was made between autotrophic and heterotrophic cells, and the presented phytoplankton groups may therefore contain both types. The carbon content of larger protozooplankton (mainly ciliates) was calculated using a conservative conversion factor of $0.08 \mathrm{pg}$ $\mathrm{C} \mu \mathrm{m}^{3}$ according to Garrison and Buck (1989). In addition to phytoplankton, faecal pellets were also enumerated and measured (length, width) in the sediment trap sub-samples.

Mesozooplankton was collected in all mesocosms using a $30 \mathrm{~cm}$ diameter, $90 \mu \mathrm{m}$ mesh net hauled vertically from the bottom of the mesocosms before deployment of the sediment traps. On August 29 the entire content on each mesocosm was pumped through a $90 \mu \mathrm{m}$ mesh net for determination of total zooplankton biomass. Mesozooplankton samples were fixed in $4 \%$ buffered formaldehyde and later analysed under a Wild M10 dissecting microscope for species and body size. Mesozooplankton abundance was converted into carbon by species, stage and sizespecific values from the literature (e.g. Båmstedt, 1986; Båmstedt et al., 1990; Widdows, 1991; Karlson and Båmstedt, 1994; Blom et al. 1989).

Surface irradiance (PAR) was registered continuously and data was stored as average values every 10 minutes in a Li-Cor Li-1000 data logger. Salinity (psu) and temperature $\left({ }^{\circ} \mathrm{C}\right)$ were measured follow- 

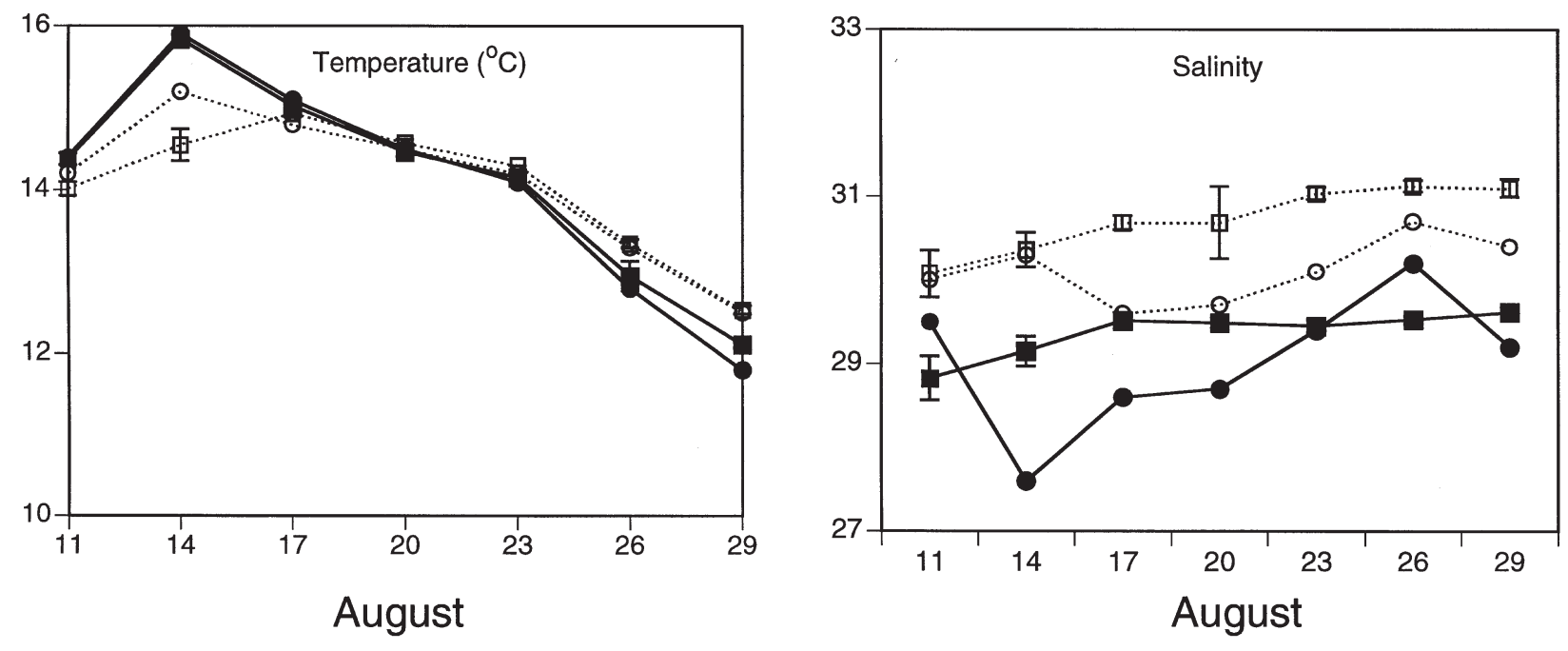

$\rightarrow$ Enclosures $2 \mathrm{~m} \quad$.. $₫ . . \quad$ Enclosures $6 \mathrm{~m}$

$\rightarrow$ Sea $2 \mathrm{~m} \quad$..๑.. Sea $6 \mathrm{~m}$

FIG. 1. - Temperature $\left({ }^{\circ} \mathrm{C}\right)(\mathrm{A})$ and salinity (psu) (B) in the enclosures and in the sea at 2 and $6 \mathrm{~m}$ depth.

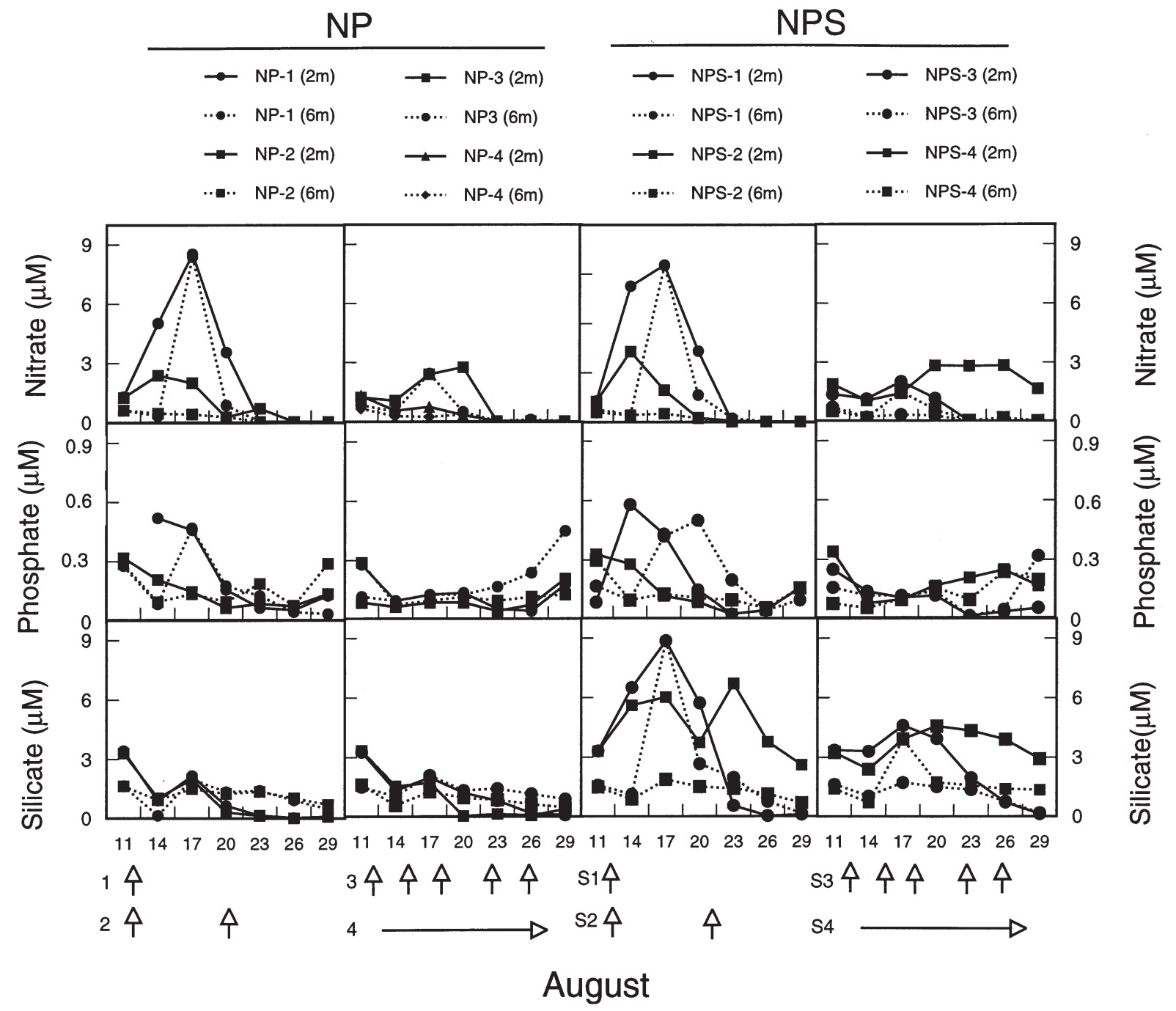

FIG. 2. - Concentrations of nitrate, phosphate and silicate in $\mu \mathrm{M}$ in all enclosures at 2 and $6 \mathrm{~m}$ depth. Vertical arrows indicate day of nutrient additions, while the horizontal arrows represent continuous nutrient additions. Note different scales on y-axes. 
ing the sampling routine with a SeaCat profiler (Sea Bird instruments).

Response to treatments (nutrient regimes vs. nutrient pulsing) was tested for statistical significance at $95 \%$ level with one-way analysis of variance (ANOVA, type III model) or a student t-test using the statistical packages StatView 5.0 (SAS Inst. inc) and Excel 8.0. The tests were performed on average values from each enclosure, with each of the four nutrient frequencies as level $(\mathrm{n}=8)$.

\section{RESULTS}

\section{Daily irradiance, temperature and salinity}

The daily irradiance ranged between 7 and 40 mol photons $\mathrm{m}^{-2} \mathrm{~d}^{-1}$, with an overall average of 26 mol photons $\mathrm{m}^{-2} \mathrm{~d}^{-1}$ (data not shown). There was a

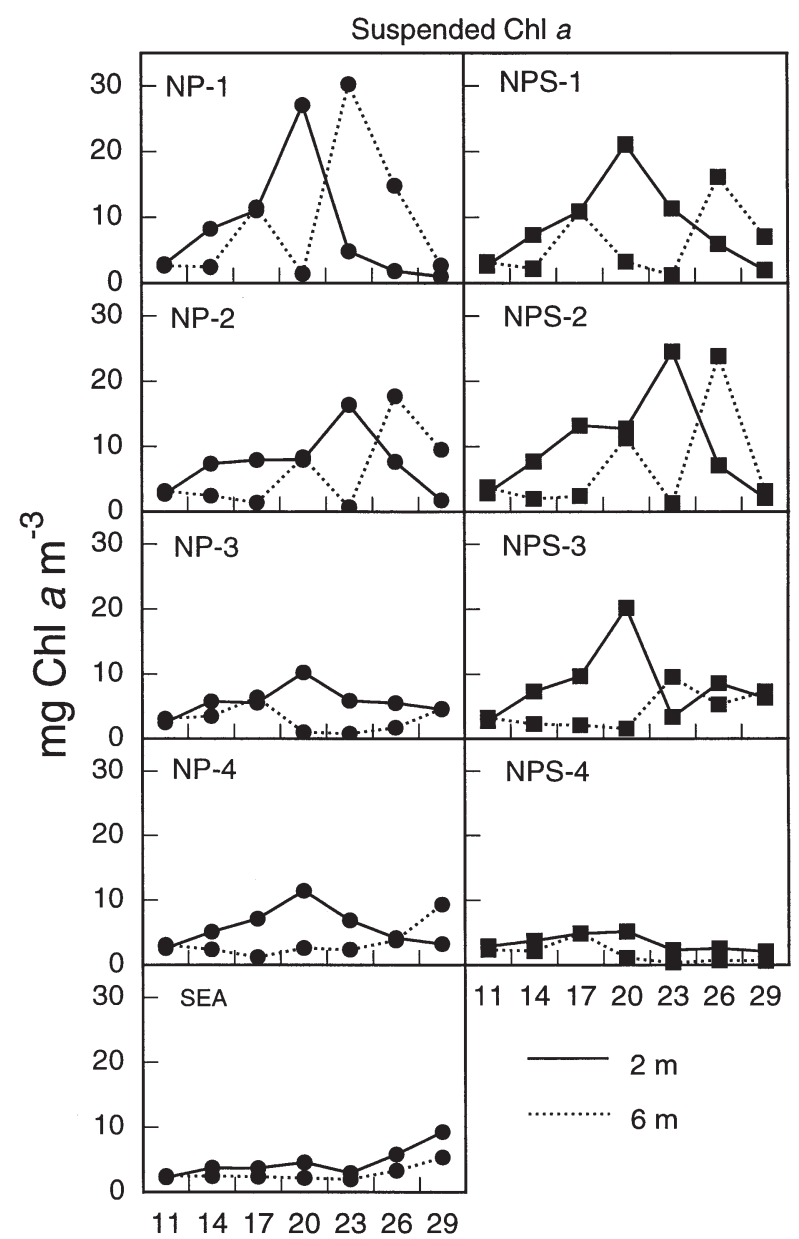

August

FIG. 3. - Suspended concentrations of chlorophyll $a\left(\mathrm{mg} \mathrm{Chl} a \mathrm{~m}^{-3}\right)$ in the enclosures and in the sea at 2 and $6 \mathrm{~m}$ depth. slight increase in daily irradiance after August 21, and the average before and after this date was 20 and 32 mol photons $\mathrm{m}^{-2} \mathrm{~d}^{-1}$ respectively. Throughout the entire period, the temperature in the enclosures followed the temperature development in the surrounding sea; gradually declining from $15-16^{\circ} \mathrm{C}$ at start to $11-12^{\circ} \mathrm{C}$ at the end (Fig. 1). Except for the first week, the temperature was similar at 2 and $6 \mathrm{~m}$. Average temperature in the enclosures for the whole period was $14^{\circ} \mathrm{C}$. The enclosures had a denser layer (30-31 psu) underneath a less saline one (about 29 psu) (Fig. 1). For comparison, the average salinity recorded in the surrounding sea was 29 psu at $2 \mathrm{~m}$ and 30 psu at $6 \mathrm{~m}$ depth (Fig. 1).

\section{Nutrients}

Nutrient samples were taken on August 11 prior to nutrient additions and they therefore represent ini-

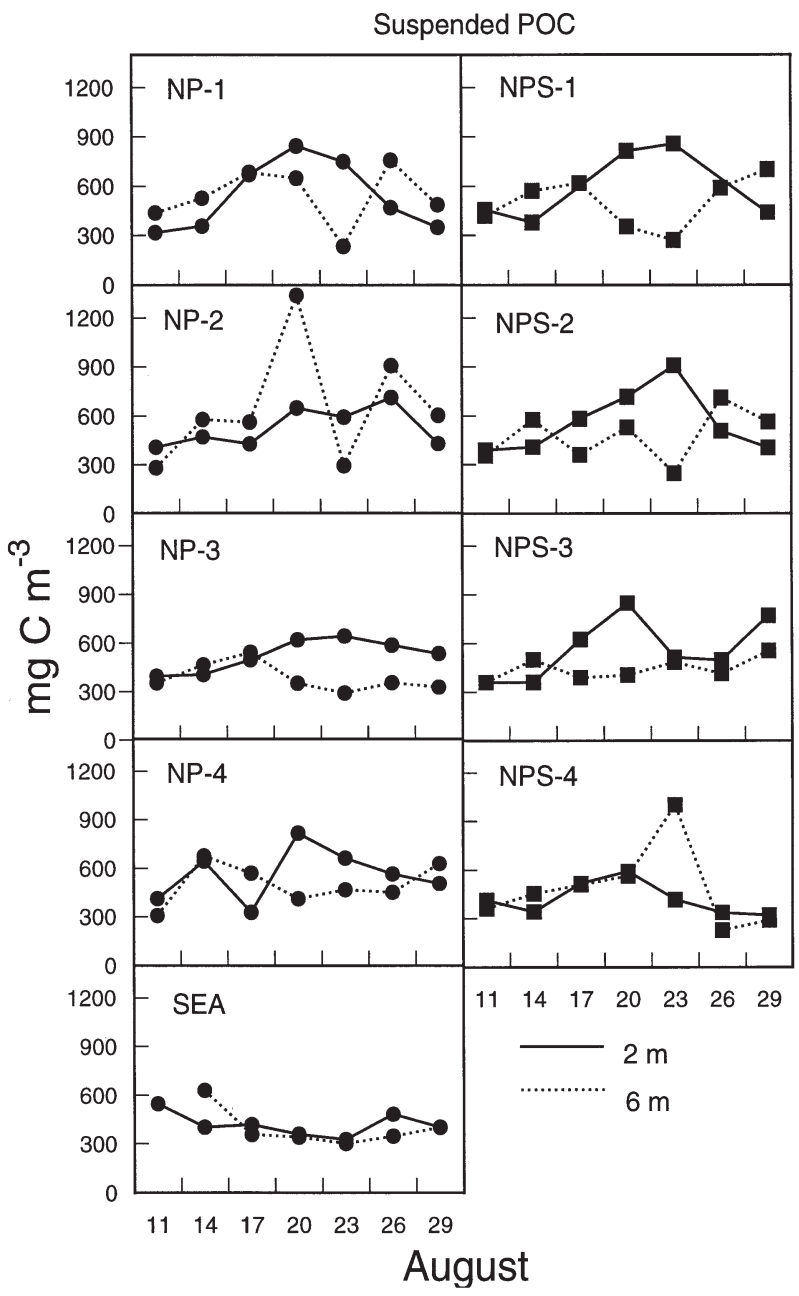

FIG. 4. - Suspended concentrations of particulate organic matter $\left(\mathrm{mg} \mathrm{C} \mathrm{m}^{-3}\right)$ in the enclosures and in the sea at 2 and $6 \mathrm{~m}$ depth. 
tial nutrient concentrations. Nitrate was relatively rapidly consumed and concentrations fell below the detection limit (ca $0.05 \mu \mathrm{M}$ ) by August 23 in all enclosures except NPS-4 (Fig. 2). Phosphate decreased more slowly in NP-1 and NPS-1 than in the other enclosures. The other enclosures had a lower average concentration of phosphate with a small increase towards the end, probably a result of nutrient addition frequencies.

Except for the initial load of silicate (which was high, about $3 \mu \mathrm{M}$ ), the concentrations of silicate in the NP enclosures were always below $3 \mu \mathrm{M}$ (Fig. 2). However, the NPS enclosures never became totally silicate-depleted at $6 \mathrm{~m}$ depth. In NPS- 1 silicate was rapidly consumed after August 18, although a depletion apparently did not occur until the last day of the experiment. The consumption of silicate appeared slower in NPS-3 than in NPS-1, and in NPS-2 and NPS-4 silicate never became depleted during the experiment (Fig. 2).

\section{Suspended chlorophyll $a$, POC and primary production}

The different nutrient regimes (NP vs. NPS) did not result in statistical differences in integrated $\mathrm{Chl}$ $a$ concentrations among the treatments (ANOVA, $p>0.05$ ). However, the frequency of nutrient additions had a significant effect, and the concentrations of Chl $a$ was significantly higher (ANOVA, $\mathrm{p}<0.05)$ in the one- and two-pulsed enclosures (NP-1, NPS-1, NP-2 and NPS-2) than in the two enclosures with a daily addition of nutrients (NP-4 and NPS-4). The enclosures receiving nutrients every third day (NP-3 and NPS-3) did not differ from the others.

Distinct blooms (measured as $\mathrm{Chl} a$ ) developed in the 1- and 2- pulsed enclosures and NPS-3 about midway through the experiment, and declined rapidly thereafter (Fig. 3). The lower and less variable concentrations of Chl $a$ at $6 \mathrm{~m}$ depth were general for the 3- and 4- enclosures (except NPS-3) compared to the pulsed enclosures, probably reflecting the low sedimentation rates of $\mathrm{Chl} a$.

Particulate organic carbon (POC) followed the development of Chl $a$ in all enclosures and was higher in the nutrient-pulsed enclosures (1 and 2) than in the 3 and 4 enclosures (Fig. 4). However, this trend was not statistically significant (ANOVA, $\mathrm{p}>$ 0.05). Except in enclosures NP-2 and NPS-4, the POC concentrations were on average higher at $2 \mathrm{~m}$ than at $6 \mathrm{~m}$ depth. The lowest concentrations of POC

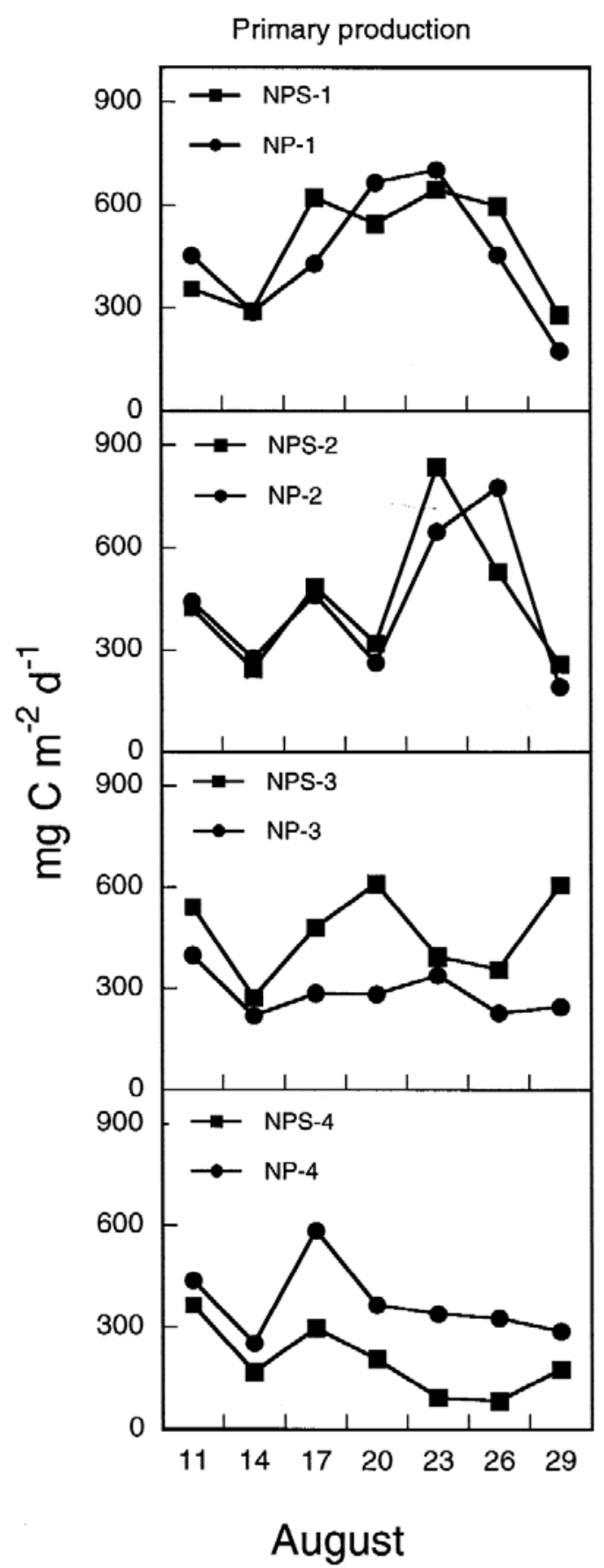

FIG. 5. - Primary production $\left(\mathrm{mg} \mathrm{C} \mathrm{m}^{-2} \mathrm{~d}^{-1}\right)$ in the different treatments. Values are integrated to $8 \mathrm{~m}$ depth assuming measurement at $2 \mathrm{~m}$ is representative for the depth interval 0-4 $\mathrm{m}$, and measurement at $6 \mathrm{~m}$ is representative for the 4-8 $\mathrm{m}$ depth interval.

were found in enclosures without addition of DSi, particularly in replicates NP-2 and NP-3.

The integrated primary production for the whole experimental period decreased with the decrease in pulsing of nutrients in the NPS mesocosm from 9.1, 8.8, 8.3 to $3.6 \mathrm{~g} \mathrm{C} \mathrm{m}^{-2}$ in the NPS-1, NPS-2, NPS-3 and the NPS-4 mesocosm respectively (Fig. 5). 
TABLE 1. - Initial concentrations $\left(10^{3}\right.$ cells $\left.1^{-1}\right)$ of diatoms, flagellates, dinoflagellates and Phaeocystis pouchetii (single cells) in enclosures (prior to nutrient additions) and in the sea on August 11. Numbers for the enclosures represent average concentrations \pm SD. No cells detected is indicated by -.

\begin{tabular}{lcccc}
\hline & Diatoms & Flagellates & Dinoflagellates & Phaeocystis pouchetii. \\
\hline Enclosures & $19 \pm 9$ & $2450 \pm 1050$ & $41 \pm 17$ & $9 \pm 9$ \\
SEA & 21 & 1335 & 21 & - \\
\hline
\end{tabular}
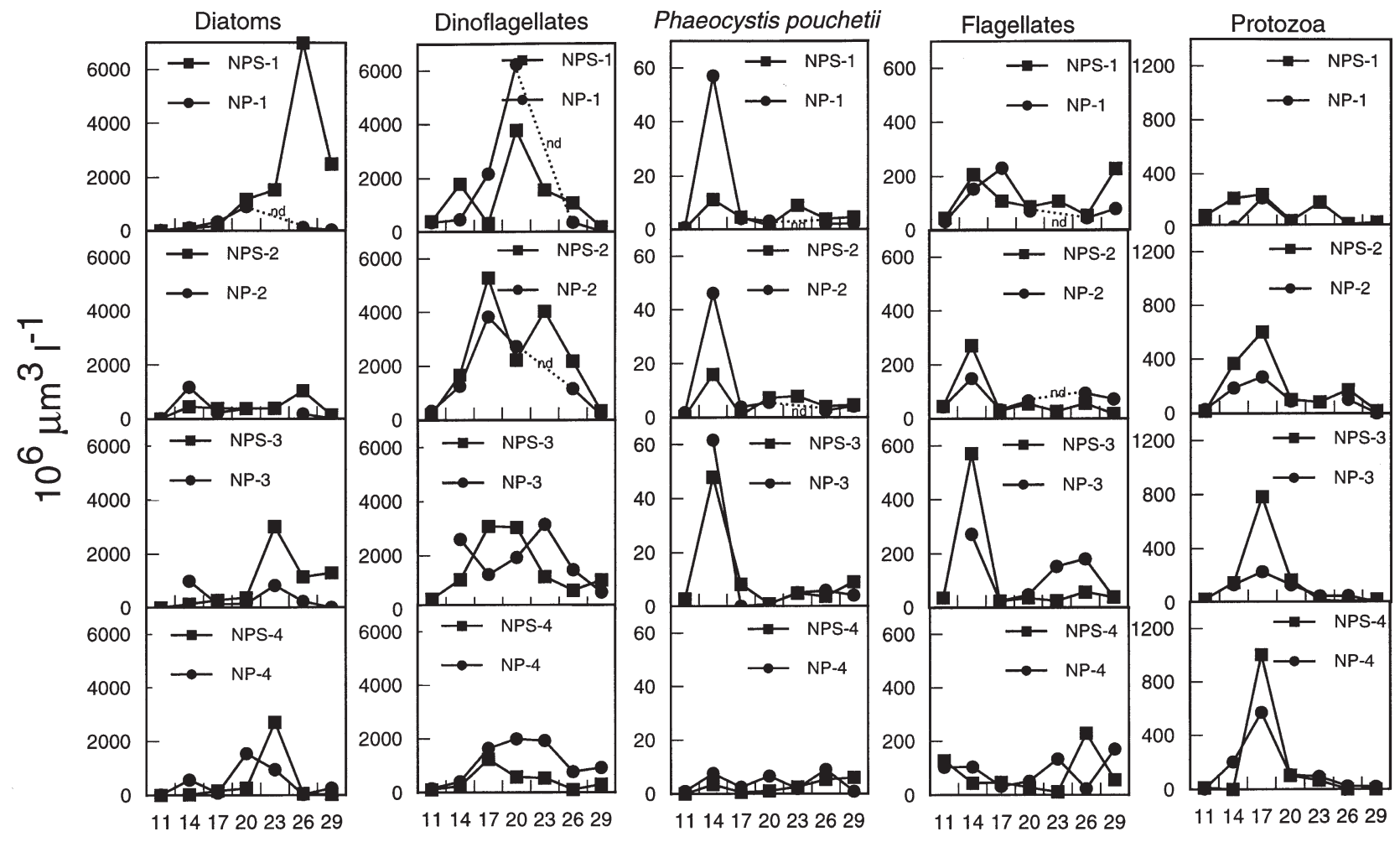

August

FIG. 6. - Biovolume $\left(10^{3} \mu \mathrm{m}^{3}\right)$ of diatoms, dinoflagellates, Phaeocystis pouchetii, flagellates and protozoa at $2 \mathrm{~m}$ depth. Note different scales on the axes. Data missing are denoted with a dashed line and "nd".

There was no such trend for the mesocosms that did not receive silicate $\left(8.5,8.6,5.3\right.$ and $7.0 \mathrm{~g} \mathrm{C} \mathrm{m}^{-2}$ for the NP-1, NP-2, NP-3 and NP-4 mesocosm respectively). However, when pulsing of nutrients decreased, the peaks of primary production were lower and occurred earlier in all mesocosms (Fig. 5).

\section{Suspended phytoplankton}

The concentration of diatoms in the intake water (i.e. the inoculum) was low (Table 1), and a shift in phytoplankton composition from non-silicate demanding species to diatoms only occurred in one of the NPS enclosures, NPS-1, where dinoflagellates were replaced by diatoms (in terms of biovolume) on August 26 (Fig. 6). This bloom of diatoms in NPS-1 was also reflected as a decline in Si concentrations after August 20 (Fig. 2). Minor "blooms" of diatoms also appeared in NPS-3 and NPS-4 on August 23 (Fig. 6). The increase in diatom biomass in NPS-4 did not result in declined $\mathrm{Si}$ concentrations. All NP enclosures had generally low biomass of diatoms, as they were probably limited by $\mathrm{Si}$ after approximately one week into the experiment. Rhizosolenia fragilissima was the dominating diatom species in all the enclosures where diatoms appeared (data not shown).

In all enclosures except NPS-1 the dinoflagellates were the dominating phytoplankton group (in terms of biovolume), with Gyrodinium aureolum as the bloom species (data not shown). The response to nutrient pulsing appeared more pronounced for the 


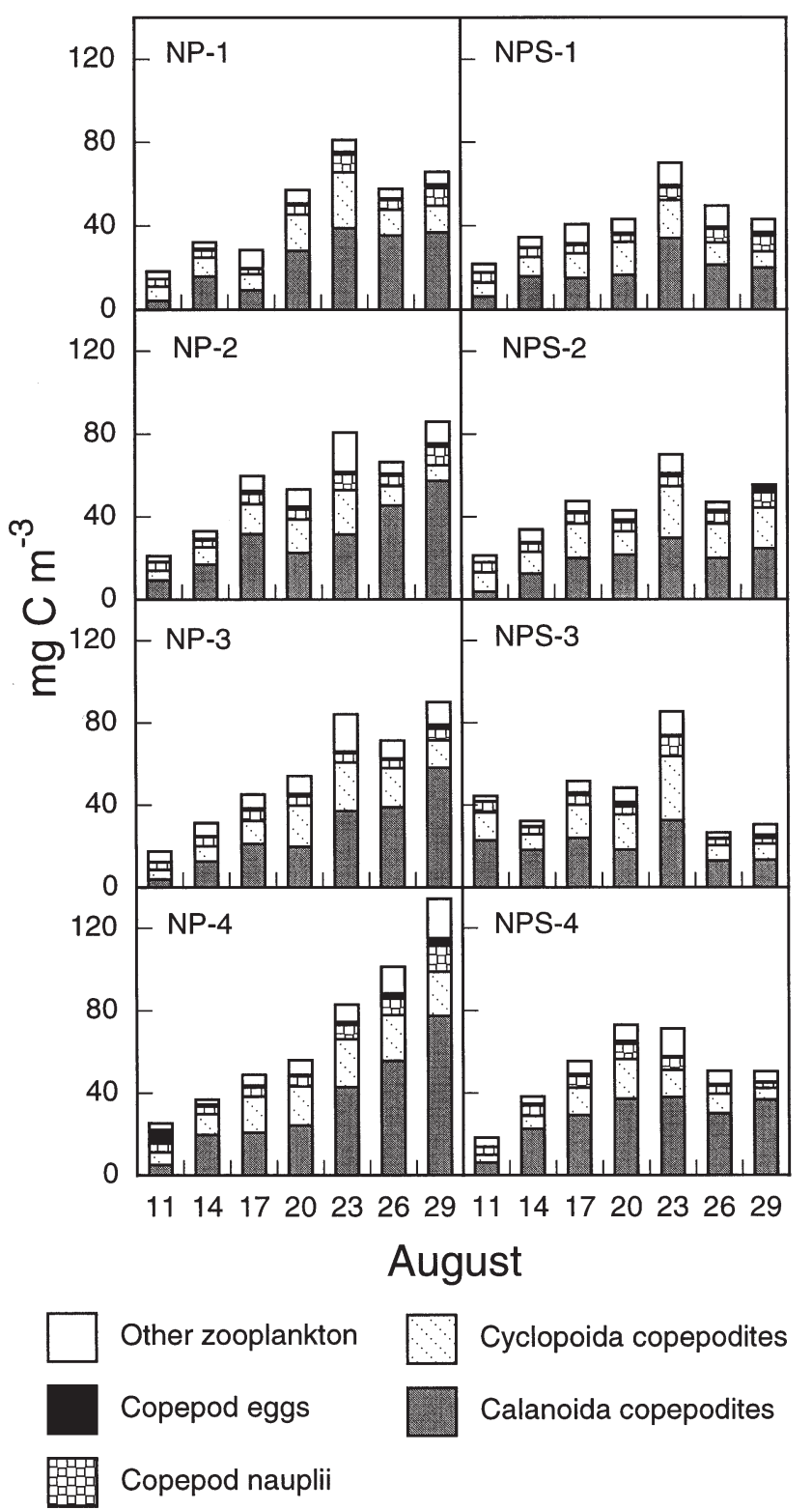

FIG. 7. - Composition and temporal development of mesozooplankton $>90 \mu \mathrm{m}$ and copepod eggs (free in the water column) in the different enclosures.

dinoflagellates than the diatoms (Fig. 6), as there were significantly more $G$. aureolum in the 2pulsed enclosures than in the 4-pulsed enclosures (ANOVA, $\mathrm{p}<0.05$ ). No statistically significant effect of nutrient pulsing on the average concentrations of diatoms was found (ANOVA, $\mathrm{p}>0.5$ ).

All enclosures except NP-4 and NPS-4 showed blooms of Phaeocystis pouchetii (single cells) and small flagellates (1-5 $\mu \mathrm{m}$ diameter). Flagellated species (dominated by small unidentified cells 2-5 $\mu \mathrm{m})$ followed the same development as $P$. pouchetii, but the differences between the NP and NPS enclosures were smaller (Fig. 6).

\section{Zooplankton composition}

The biomass of total mesozooplankton ( $>90 \mu \mathrm{m})$ was significantly higher in the NP than in the NPS enclosures (two-tailed t-test, $\mathrm{p}=0.016$ ). There were no statistical differences in the abundance of copepod nauplii and eggs between the NP and NPS enclosures, and the observed difference may have been due to higher growth in the NP than in the NPS enclosures. The biomass/abundance ratio of the calanoid copepods also showed a slight increase during the last week of the experiment, while that of the cyclopoids was more stable (data not shown). Further, there was a pronounced increase in mesozooplankton biomass from the beginning to the end of the experiment in the NP enclosures, while in the NPS enclosures the development was more bellshaped with maximum concentrations around August 23 (Fig. 7). The frequency of nutrient pulsing had no statistically significant effect on total zooplankton biomass (one-way ANOVA, p > 0.5), although there was a trend of increasing biomass from the one-pulsed enclosures to the ones getting a continuous supply. At the end of the experiment the highest biomass was obtained in enclosure NP-4, with almost $140 \mathrm{mg} \mathrm{C} \mathrm{m}^{-3}$.

Calanoid copepods dominated in terms of biomass, but Oithona spp. was an important contributor in all enclosures (Fig. 7). Of the calanoids, the small species Paracalanus spp. and Pseudocalanus spp. contributed on average $40-45 \%$ of the biomass, while Calanus finmarchicus and C. helgolandicus made up 20-25\%.

The protist biomass was lowest in the enclosures NP-1 and NPS-1. In all other enclosures, maxima of about $400-800 * 10^{6} \mu \mathrm{m}^{3} \mathrm{l}^{-1}$ occurred on August 17, just after the bloom of flagellates (Fig. 6). In general, maxima were higher in the NPS than in the NP enclosures.

\section{Vertical flux}

Sedimentation of POC and Chl $a$ was relatively low until August 23 (range 200-500 $\mathrm{mg} \mathrm{m}^{-2} \mathrm{~d}^{-1}$ and 1$5 \mathrm{mg} \mathrm{m}^{-2} \mathrm{~d}^{-1}$ for POC and Chl $a$ respectively), while during the last 6 days of the experiment the sedimentation rates increased (Figs. 8, 9). There was a statistically significant effect of the pulse frequency on the sedimentation of Chl $a$ (ANOVA, p = 0.04), although the same trend was not significant for POC (ANOVA, $\mathrm{p}=0.5$ ). The sedimentation of POC was positively correlated with the suspended concentra- 

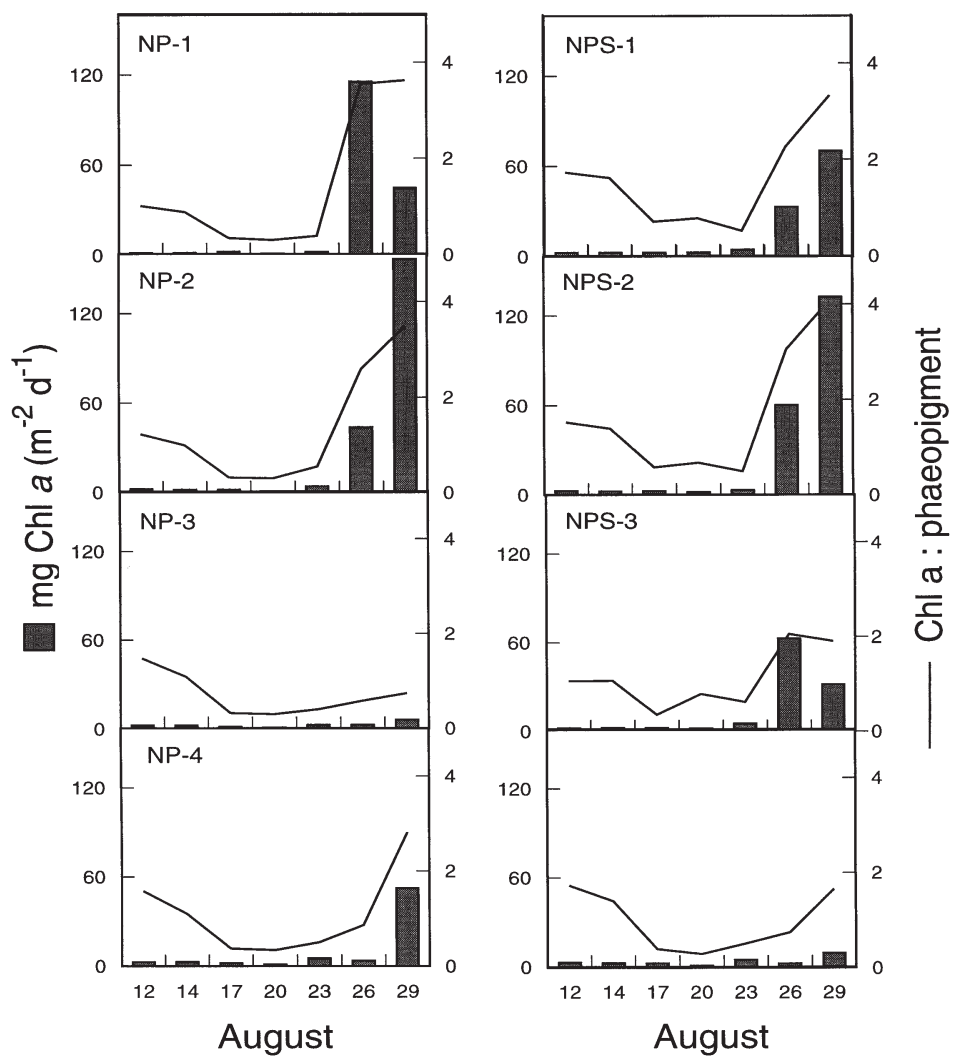

FIG. 8. - Sedimented chlorophyll $a$ (mg Chl $a \mathrm{~m}^{-2} \mathrm{~d}^{-1}$, bars) and the Chl $a$ :phaeopigment ratio (by weight, line) in the enclosures. Note different scales on right and left axis.

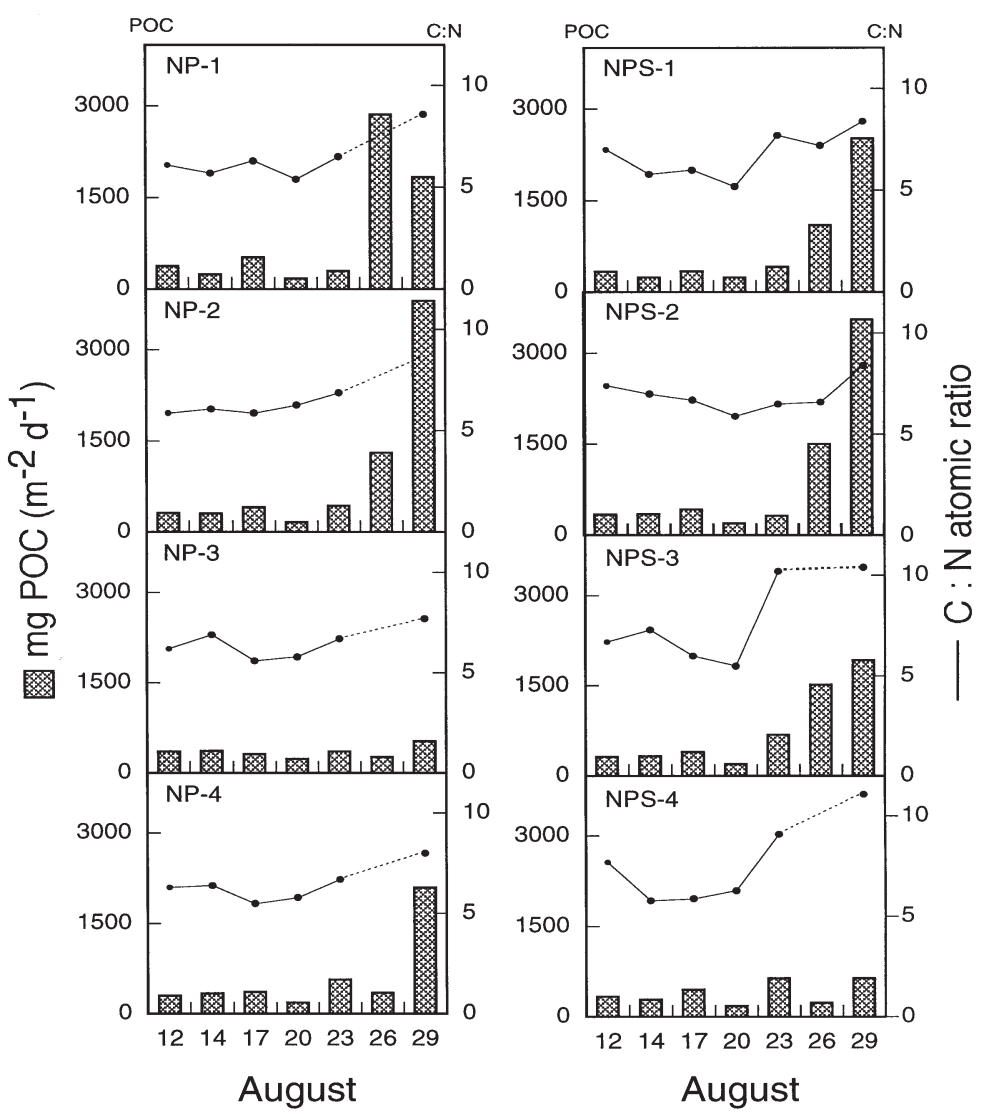

FIG. 9. - Sedimented POC $\left(\mathrm{mg} \mathrm{C} \mathrm{m}^{-2} \mathrm{~d}^{-1}\right)$ and the $\mathrm{C}: \mathrm{N}$ atomic ratio in the enclosures. 


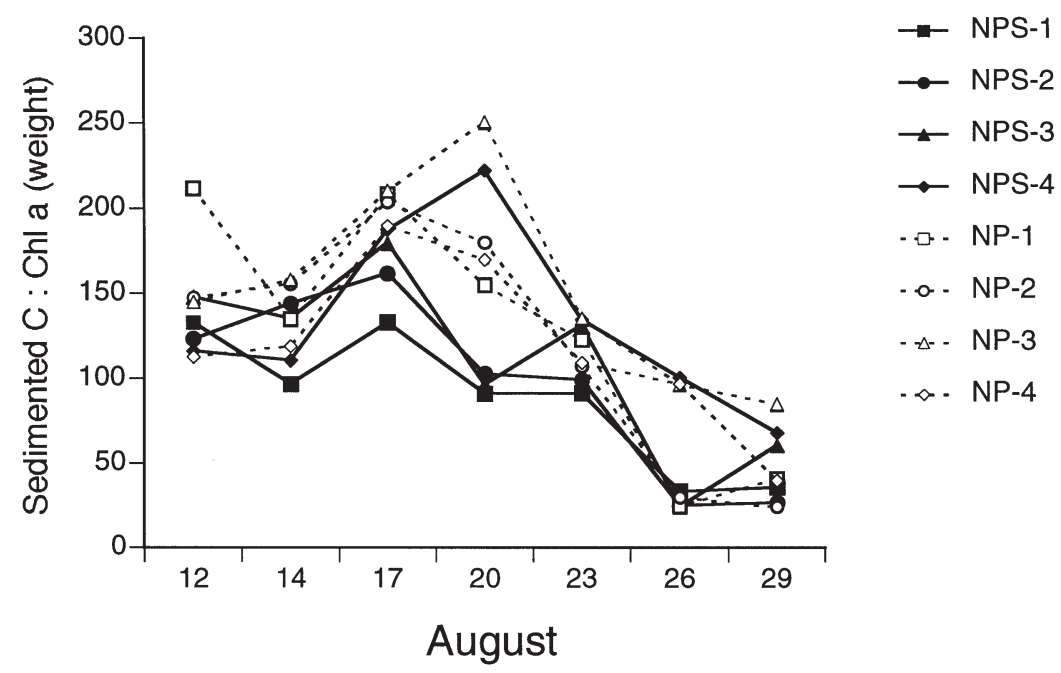

FIG. 10. - Development of the carbon:chlorophyll $a$ (weight) ratio in all the enclosures.

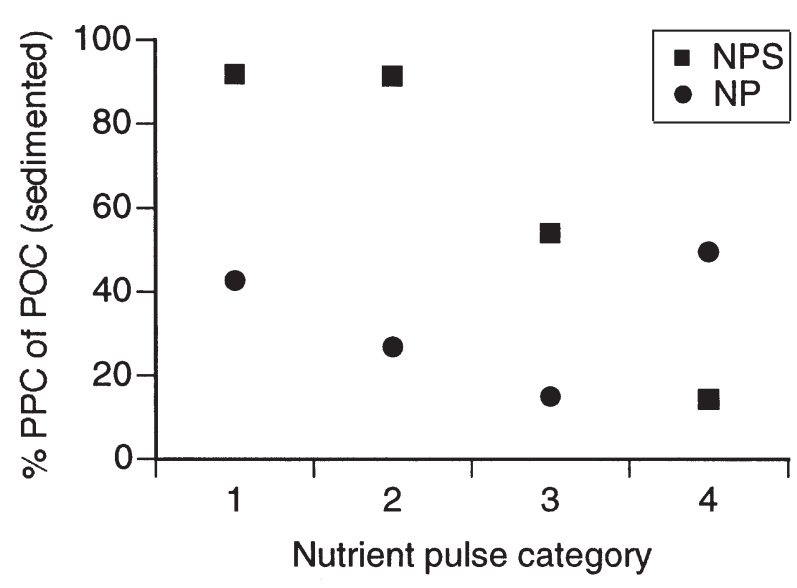

FIG. 11. - Relative contribution of phytoplankton carbon (PPC) to particulate organic matter (POC) at the different nutrient addition intervals in the NP and NPS enclosures. Numbers are based on average sedimentation rates for the various enclosures during the duration of the experiment (19 days).

tion of POC (slope $=0.47, \mathrm{r}^{2}=0.57, \mathrm{p}=0.03$ ). The highest average sedimentation rates of both Chl $a$ and $\mathrm{POC}$ were found in the enclosures receiving nutrients in two pulses, but there were only minor differences in sedimentation rates between the enclosures receiving nutrients in one pulse compared to two pulses. At the same time, the differences between enclosures receiving nutrients every third day or continuously were small. Sedimentation of phaeopigments followed the same trend as $\mathrm{Chl} a$, although small maxima were found in all enclosures on August 17 (Fig. 8).

$\mathrm{C}: \mathrm{N}$ (atomic) ratios were within the range 6-11 during the experimental period (Fig. 9), which is typical for spring bloom situations. In all enclosures the ratio increased towards the end of the experiment, indicating N-limitation of sedimented phytoplankton. Accordingly, the $\mathrm{C}: \mathrm{Chl} a$ ratio decreased in all enclosures towards the end of the experiment (Fig. 10).

The total contribution of phytoplankton carbon (PPC) to sedimented POC was high in all enclosures (Fig. 11). The fraction of PPC to POC was generally higher in the NPS enclosures than in the NP enclosures, except for NP-4. The lowest (average) contribution of PPC (and hence the highest fraction of detritus) was found in NPS-4 (14\%) and NP-3 $(15 \%)$, while the highest was found in NPS-1 (93\%)

TABLE 2. - Total C-fixation $\left(\mathrm{g} \mathrm{m}^{-2}\right)$, sedimented $\mathrm{Chl} a\left(\mathrm{~g} \mathrm{~m}^{-2}\right)$, particulate organic carbon (POC, $\left.\mathrm{g} \mathrm{m}^{-2}\right)$, phytoplankton carbon (PPC, $\left.\mathrm{g} \mathrm{m}^{-2}\right)$ and faecal pellet carbon FPC $\left(\mathrm{g} \mathrm{m}^{-2}\right)$ in each enclosure, integrated over the total duration of the experiment (19 days).

\begin{tabular}{|c|c|c|c|c|c|}
\hline & $\begin{array}{c}\mathrm{C}-\text { fixation } \\
\left(\mathrm{g} \mathrm{m}^{-2}\right)\end{array}$ & $\begin{array}{l}\text { Sedimented Chl } a \\
\quad\left(\mathrm{mg} \mathrm{m}^{-2}\right)\end{array}$ & $\begin{array}{l}\text { Sedimented POC } \\
\left.\qquad \mathrm{g} \mathrm{m}^{-2}\right)\end{array}$ & $\underset{\left(\mathrm{g} \mathrm{m}^{-2}\right)}{\text { Sedimented PPC }}$ & $\begin{array}{l}\text { Sedimented FPC } \\
\qquad\left(\mathrm{g} \mathrm{m}^{-2}\right)\end{array}$ \\
\hline NPS-1 & 9.1 & 60 & 12.7 & 11.8 & 0.3 \\
\hline NPS-2 & 8.5 & 67 & 16.1 & 14.7 & 0.2 \\
\hline NPS-3 & 8.3 & 51 & 13.9 & 7.5 & 0.2 \\
\hline NPS-4 & 3.6 & 21 & 7.3 & 1.1 & 0.2 \\
\hline NP-1 & 8.5 & 70 & 16.8 & 7.1 & 0.1 \\
\hline NP-2 & 8.6 & 54 & 16.1 & 4.3 & 0.1 \\
\hline NP-3 & 5.3 & 35 & 6.3 & 0.9 & 0.1 \\
\hline NP-4 & 7.0 & 37 & 10.2 & 5.1 & 0.2 \\
\hline
\end{tabular}


and NPS-2 (91\%) (Table 2). The dinoflagellates, and especially Gyrodinium aureolum, were important contributors to the vertical PPC flux. $P$. pouchetii (single cells) was the only species showing increased sedimentation rates from the 1-enclosures to the 4-enclosures (although not statistically significant). The vertical flux of faecal pellets was low in all enclosures, and the contribution to the POC flux never exceeded 4\% (Svensen and Nejstgaard, unpublished).

\section{DISCUSSION}

Studies on the effect of nutrient pulses in marine ecosystems are rare, and often only include phytoplankton (but see Cottingham and Schindler, 2000, for an example from freshwater systems). While chemostat experiments often investigate competition between different phytoplankton species under various degrees of pulsing, we intended to study the effect of nutrient pulses in a more complex but controlled ecosystem. The present mesocosm experiment was designed to test the effect of nutrient pulsing on three trophic levels (phytoplankton, microzooplankton and mesozooplankton) in addition to vertical flux of biogenic matter.

\section{Phytoplankton species succession and inoculum}

The diatoms became dominating (in terms of biovolume) only in the NPS-1 enclosure (Fig. 6), although silicate concentrations were generally high (Fig. 2) in the NPS enclosures. Although there were generally more diatoms in the NPS compared to the $\mathrm{NP}$ enclosures, smaller peaks of diatom biovolume also occurred in the NP enclosures. Previous mesocosm experiments have demonstrated that diatoms generally dominate at $\mathrm{Si}$ concentrations $>2 \mu \mathrm{M}$ (Egge and Aksnes, 1992). Accordingly, a shift in species composition from flagellate to diatom dominance was expected in the NPS enclosures. From August 11-20, before $\mathrm{N}$ became depleted in some enclosures, the average Si:N molar ratio in NP was 1.13 compared to 2.9 in NPS at $2 \mathrm{~m}$ depth. $\mathrm{N}$ and $\mathrm{Si}$ are utilised in a ratio close to 1 , and diatoms could thus potentially grow in both NP and NPS. In a continuous experiment, Sommer (1994) noted that a shift from flagellate to diatom dominance occurred at a very high $\mathrm{Si}: \mathrm{N}$ ratio of $25: 1$. This deviates from the range in $\mathrm{Si}: \mathrm{N}$ ratios causing a shift from diatoms to flagellates in nature (Sommer, 1994, and refer- ences therein). Sommer concluded that the discrepancy between the continuous cultures and nature could be explained by various hypotheses, such as the $\mathrm{Si}$ requirements of the dominating diatom, selective grazing and environmental variability such as vertical transport through the light gradient (Sommer, 1994).

In this large-scale experiment an additional factor, the initial cell concentrations (i.e. the inoculum) in the enclosures, may have had a strong influence on the dynamics of phytoplankton. The phytoplankton in the intake water was a collection of typical autumn (and possibly post-bloom) species. Relatively few diatoms and Phaeocystis sp. single cells (no colonies) were present, and dinoflagellates dominated (Table 1). It should however be noted that small flagellated cells dominated the inoculum in terms of cells $1^{-1}$. We would like to emphasise that the inoculum and hence the seasonal timing of the experiments should also be taken into account when similar experiments are planned and performed. In other words, experiments conducted at different seasons cannot be expected to show the same response to nutrient treatments. This was also described in a marine microcosm experiment where the response to treatments (turbulence) depended on the initial population of phytoplankton and hence the seasonal timing of the experiment (Estrada et al., 1987). Similarly, nutrient supply to a recipient may give rise to different effects over the course of the year. It should, however, be noted that the relative abundance of different species in the inoculum has been reported to be of minor importance in flow-through cultures where the final equilibrium was found to be totally nutrient controlled (Sommer, 1984). This may reflect the difference in complexity between a mesocosm experiment and a culture experiment with only one trophic level. For instance, steady-state conditions are usually not achieved in mesocosm experiments, and a comparison with flow through cultures in equilibrium is probably not adequate.

\section{Nutrient pulsing and the primary producers}

The dinoflagellate Gyrodinium aureolum was the species showing the most pronounced response to nutrient pulsing. Species showing rapid increase after nutrient enrichment (and decline under impoverished conditions) have been termed "growth strategists", while species with a weak or insignificant growth rate response have been regarded as 
"affinity or storage strategists" (Sommer, 1989). The higher abundance of $G$. aureolum in the 1 and 2pulsed enclosures compared to the more frequently pulsed may indicate that this species is a growth or r-strategist. However, typical r-strategists are usually described as small phytoplankton cells with a high uptake-affinity for nutrients (Banse, 1982), such as small flagellates. Although small phytoplankton cells may have a large physiological capacity for luxury consumption, they will not be able to take advantage of pulses of nutrients when already growing at maximal rates (Thingstad and Sakshaug, 1990). Hence, the primary effect of a nutrient pulse will be a peak in abundance of large phytoplankton (Thingstad and Sakshaug, 1990), as was the case with the dinoflagellates in this experiment.

The diatoms did not appear to respond to the various pulsed additions and generally showed one maximum (after the dinoflagellate maximum) irrespective of the frequency of nutrient additions. This was also found in a competition experiment with Lake Constance phytoplankton, in which the diatoms did not take advantage of Si pulses (Sommer, 1989). Growth and doubling rates are frequently related to concentration of nutrients within the primary producer, and do not necessarily reflect those in the surrounding water. Diatoms do not have intracellular storage of silicate, and this may explain their lack of response to Si pulses (Sommer, 1989).

Phytoplankton can store nutrients at times of high concentrations and use them for production in the absence of external supplies. As many as two to more than five generations may be fuelled from stored sources (Barnes and Hughes, 1988). Increased addition of a limited nutrient may also select for larger species (Turpin and Harrison, 1979). However, in the present mesocosm experiment nutrients (nitrate) did not become depleted until the end of the experiment (and were never depleted in NPS-4), and a selection of larger species according to the theory of Turpin and Harrison (1979) appeared not to be the case in this experiment.

\section{Grazer interactions}

The significantly higher biomass of mesozooplankton in the NP than in the NPS enclosures is consistent with previous mesocosm experiments manipulated with $\mathrm{N}, \mathrm{P}$ and $\mathrm{Si}$, in which flagellate/diatom communities developed (Nejstgaard et al., 1997; Nejstgaard et al., 2001). The authors suggested that the low reproduction and growth in the NPS mesocosms was a result of diatoms (such as Skeletonema costatum) being poor food for copepods, as also observed in laboratory experiments (e.g. Miralto et al., 1999; Turner et al., 2001, and references therein, but see also Jónasdóttir et al 1998). In the present experiment, we did not succeed in generating contrasting flagellate/diatom communities by nutrient additions $(\mathrm{N}, \mathrm{P}$ vs. N, P, $\mathrm{Si}$ ), although there were on average more diatoms in the NPS than in the NP enclosures (48 and $21 \mathrm{mg} \mathrm{C}$ $\mathrm{m}^{-3}$ respectively). There may be an effective loop of energy and nutrients through flagellates and protists to mesozooplankton that compensates for the decrease in zooplankton fertility caused by a diatom diet. We can only speculate that the composition of food for the calanoid copepods was better in the NP than in the NPS enclosures (see also discussion in Nejstgaard et al., 2001).

We hypothesised that a higher degree of "mismatch" between the grazers and phytoplankton would occur in the low-frequency pulsed enclosures (1 and 2) compared to the 3- and 4- enclosures, causing increased sedimentation rates. In accordance with this prediction, we demonstrated higher sedimentation rates of both POC and Chl $a$ in the 1- and 2- pulsed enclosures (although statistically significant only for $\mathrm{Chl} a$ ). We further demonstrated that the fraction of phytoplankton carbon (PPC) to the total flux of POC decreased with the frequency of pulsing (Fig. 10), but see NP-4. This may reflect the ability of the zooplankton to control the stock of phytoplankton under various nutrient pulses. However, an increase in sedimenting faecal pellets should be expected where the contribution of PPC was low. The flux of FPC was exceptionally low in this experiment, and we believe that this is a consequence of faecal pellet grazing (coprophagy) from the cyclopoid copepod Oithona spp. (Svensen and Nejstgaard, unpublished.). This copepod made up a large fraction of the mesozooplankton biomass, and is considered an efficient flux feeder. Thus the composition of sedimented matter (POC, PPC, FPC) does not reflect match-mismatch in a straightforward manner, but is further modulated by the different feeding modes of zooplankton.

A limnic mesocosm study demonstrated that large zooplankton grazers such as Daphnia could modify and buffer the response of the primary producers to (small) nutrient pulses (Cottingham and Schindler, 2000). The authors conclude that grazer size structure is an informative predictor of phyto- 
plankton sensitivity to small nutrient pulses, but that other factors need to be incorporated into predictions for larger perturbations (Cottingham and Schindler, 2000). A similar coupling to mesozooplankton was pointed out by Aksnes and Wassmann (1993). Cladocera and protozooplankton can increase their grazing pressure on phytoplankton compared to mesozooplankton as a result of parthenogenesis and high doubling rates. The difference in zooplankton composition may thus give rise to changes in the pelagic-benthic coupling during eutrophication (Aksnes and Wassmann, 1993).

The small and early-culminated blooms of flagellates and Phaeocystis pouchetii in NP-4 and NPS-4 may be a result of a rapid response of the microzooplankton. This is suggested by the increase in protozoan biovolume (Fig. 6). Thus, instead of contributing to the sedimentation of carbon, this biomass may have been channelled into the grazer food chain. However, this was not reflected as increased biomass of mesozooplankton. Previous mesocosm experiments have demonstrated higher secondary production in flagellate-based mesocosms (Nejstgaard et al., 1997; Nejstgaard et al., 2001). This is in contrast with the view that diatom-based food chains are the most effective at transferring carbon to higher trophic levels.

\section{What regulated export production?}

Sedimentation rates of Chl $a$ and POC were positively correlated with suspended biomass, and hence influenced by the rate of nutrient pulsing. The highest biomass and sedimentation rates were found in the 2-pulsed enclosures, while the lowest biomass and vertical flux appeared in the enclosures receiving continuous supply. The fraction of sedimented PPC to POC declined with degree of nutrient pulsing in the NPS enclosures, while the trend was corrupted in the NP enclosures caused by an increase in relative contribution of PPC in NP-4 (Fig. 10). This was according to expectations, as sedimentation of fresh material is usually connected to bloom situations in which the grazer community is not able to control phytoplankton biomass (Aksnes and Wassmann, 1993). Further, the relative contribution of PPC to POC in the sedimented material was generally lower in the NP than in the NPS enclosures,. This may be a result of the higher biomass and hence higher grazing pressure from mesozooplankton in NP than in the NPS enclosures, as well as a higher relative abundance of diatoms in NPS-1. On the other hand, in more regenerative systems in which the supply of nutrients is continuous (although these nutrients are regenerated and this was not the case here), a larger fraction of the phytoplankton cells are grazed and hence the vertical export is governed by detritus and faecal pellets instead of PPC. It should, however, be pointed out that even in the "regenerated" systems (the 3- and 4enclosures), the contribution of PPC to POC was rather high (range 15-60\%), and thus they cannot be regarded as true regenerative systems since nutrients were supplied throughout the experiment. Among several west-Norwegian fjords the annual variability of the vertical POC export was lowest in the strongly and continuously eutrophicated fjord Nordåsvannet (Wassmann, 1991). Thus, both experimental and field evidence supports the assumption that continuous availability of nutrients results in match scenarios, decreased phytoplankton variability and higher recycling.

The vertical flux of biogenic matter in all enclosures consisted to a large extent of the toxic dinoflagellate G. aureolum. Motile cells such as dinoflagellates may easily migrate into sediment traps when positioned at shallow depths and may cause overestimation of the vertical flux of POC (Heiskanen, 1995). Heiskanen applied both preserved and unpreserved sediment traps, and calculated the overestimation caused by vertical migration from these. It is not certain to what degree migrating species may have contaminated the unpreserved sediment traps in our investigation, but we argue that migration of dinoflagellates cannot explain the differences in vertical flux found between the treatments (nutrient pulses) in this experiment. The dinoflagellate $G$. aureolum does perform vertical migration (Dahl and Brockmann, 1989; Dahl and Tangen, 1993), but the average sedimentation rates or the suspended concentration of dinoflagellates did not differ significantly between the different frequencies of nutrient additions (ANOVA, $p=0.44$ and $p=0.09$ respectively). Consequently, the dinoflagellates alone cannot explain the observed differences in sedimentation rates between the treatments.

Dinoflagellates are not reported to be important contributors to the vertical carbon flux (Sellner et al., 1993). However, Riegman et al. (1997) concluded that toxic algae may be poorly edible to zooplankton and may show high sedimentation rates. Hansen (1995) demonstrated that G. aureolum was poor food for the ciliate Favella ehrenbergii, but in the experiment it was not able to selectively avoid it. 
Contrasting results have been demonstrated for copepods actively avoiding feeding on the very similar dinoflagellate Gymnodinium mikimotoi ( $G$. aureolum and G. mikimotoi are possibly the same species, see Steidinger and Tangen, 1997). We therefore speculate that the large contribution of G. aureolum to the vertical flux was caused by low grazing pressure on this species. We further suggest that protozooplankton grazed $P$. pouchetii single cells and small flagellates, while the mesozooplankton grazed mainly microzooplankton.

\section{CONCLUSIONS}

- The frequency of nutrient pulses, varying from a single load to a continuous supply, did not affect the primary production significantly. However, there was a trend of decreasing primary production (integrated for the entire period) with decreasing nutrient pulsing in the NPS, but not in the NP enclosures.

- There were significant differences in biomass build-up (measured as $\mathrm{Chl} a$ ) in the single load enclosures (NP-1 and NPS-1) compared to the enclosures receiving nutrients constantly (NP-4 and NPS-4).

- The dinoflagellate Gyrodinium aureolum was the only phytoplankton species showing a clear response to the various nutrient pulses.

- The diatoms and dinoflagellates in the singlepulsed enclosures appeared to out-grow zooplankton grazing, because the sedimented matter generally showed higher fractions of PPC to POC in the 1- and 2- than in the 3- and 4- enclosures (except in one case).

- The biomass of mesozooplankton was significantly higher in the NP than in the NPS enclosures, probably reflecting differences in food quality in the two systems.

- The continuous supply of nutrients generated a stable food chain, greater retention and decreased export of fresh organic matter. In contrast, the enclosures receiving nutrients in pulses resembled springsituations with higher build-up of biomass and high vertical export of organic matter.

\section{ACKNOWLEDGEMENTS}

The authors thank O. Sergeeva for phytoplankton and faecal pellet analyses, S. Øygarden for $\mathrm{C}$ and $\mathrm{N}$ analyses and M. Martinussen for sampling assistance. The comments of C. Wexels Riser and C. Marrasé improved the manuscript. This research was supported by the Norwegian Research Council (NFR) and is a contribution from the Norwegian Programme Nutrients and Pelagic Marine Production (NAPP).

\section{REFERENCES}

Aksnes, D.L. and P. Wassmann. - 1993. Modeling the significance of zooplankton grazing for export production. Limnol. Oceanogr., 38: 978-985.

Banse, K. - 1982. Cell volumes, maximal growth rates of unicellular algae and ciliates, and the role of ciliates in the marine pelagial. Limnol. Oceanogr., 27: 1059-1071.

Barnes, R.S.K. and R.N. Hughes. - 1988. An introduction to marine ecology. Second edition. Oxford Blackwell Scientific Publications, London.

Båmstedt, U. - 1986. Chemical composition and energy content. In: E.D.S. Corner and S.C.M. O'Hara (eds.), The biological chemistry of marine copepods, pp. 1-58. Oxford University Press, Oxford.

Båmstedt, U., J.L. Håkansson, J. Brenner-Larsen, P.K. Björnsen, O. Geertz-Hansen and P. Tiselius. - 1990. Copepod nutritional condition and pelagic production during autumn in Kosterfjorden, western Sweden. Mar. Biol., 104: 197-208.

Blom, G., H. Otterå, T.S. Kristiansen and B. Serigstad. - 1989. The relationship between feeding conditions and production of cod fry (Gadus morhua) in a semienclosed marine ecosystem in western Norway, illustrated by use of a consumption model. ICES J. Mar. Sci. Symp., 192: 176-189.

Cottingham, K.L. and D.E. Schindler. - 2000. Effects of grazer community structure on phytoplankton response to nutrient pulses. Ecology., 81: 183-200.

Dahl, E. and U.H. Brockmann. - 1989. Does Gyrodinium aureolum perform diurnal vertical migrations? In: Okaichi, Anderson, Nemoto (eds.), Red tides: biology, environmental science and toxicology. Elsevier Science Publishing Co., Inc.

Dahl, E. and K. Tangen. - 1993. 25 years experience with Gyrodinium aureolum in Norwegian waters. In: T.J. Smayda and Y. Shimizu (eds.), Toxic phytoplankton blooms in the sea, pp. 15 21. Elsevier Science Publishers, Amsterdam.

Egge, J.K. and D.L. Aksnes. - 1992. Silicate as regulating nutrient in phytoplankton competition. Mar. Ecol. Prog. Ser., 83: 281-289.

Estrada, M., M. Alcaraz and C. Marrasé. - 1987. Effects of turbulence on the composition of phytoplankton assemblages in marine microcosms. Mar. Ecol. Prog. Ser., 38: 267-281.

Gargas, E. - 1975. A manual for phytoplankton primary production studies in the Baltic, 2nd ed. Water Quality Institute, Hørsholm, p. 88.

Garrison, D.L. and K.R. Buck. - 1989. Protozooplankton in the Weddel Sea, Antarctica: abundance and distribution in the iceedge zone. J. Polar. Biol., 9: 341-351.

Hansen, P.J. - 1995. Growth and grazing response of a ciliate feeding on the red tide dinoflagellate Gyrodinium aureolum in monoculture and in mixture with a non-toxic alga. Mar. Ecol. Prog. Ser., 121: 65-72.

Heiskanen, A.-S. - 1995. Contamination of sediment trap fluxes by vertically migrating phototrophic micro-organisms in the coastal Baltic Sea. Mar. Ecol. Prog. Ser., 122: 45-58.

Heiskanen, A.S., T. Tamminen and K. Gundersen. - 1996. Impact of planctonic food web structure on nutrient retention and loss from a late summer pelagic system in the coastal northern Baltic Sea. Mar. Ecol. Prog. Ser., 145: 195-208.

Jacobsen, A., J.K. Egge and B.R. Heimdal. - 1995. Effects of increased concentration of nitrate and phosphate during a spring bloom experiment in mesocosm. J. exp. Mar. Biol. Ecol., 187: 239-251.

Jónasdóttir, S.H., T. Kiørboe, K.W. Tang, M. St John, A.W. Visser, E. Saiz and H.G. Dam. - 1998. Role of diatoms in copepod production: good, harmless or toxic? Mar. Ecol. Prog. Ser. 172: 305-308. 
Karlson, K. and U. Båmstedt. - 1994. Planktivorous predation on copepods. Evaluation of mandible remains in predator guts as a quantitative estimate of predation. Mar. Ecol. Prog. Ser., 108: 79-89.

Miralto, A., G. Barone, G. Romano, S.A. Poulet, A. Ianora, G.L. Russo, I. Buttino, G. Mazzarella, M. Laabir, M. Cabrinik and M.G. Giacobbe. - 1999. The insidious effect of diatoms on copepod reproduction. Nature, 402: 173-176

Nejstgaard, J.C., I. Gismervik and P.T. Solberg. - 1997. Feeding and reproduction by Calanus finmarchicus and microzooplankton grazing during mesocosm blooms of diatoms and the coccolithophore Emiliania huxleyi. Mar. Ecol. Prog. Ser., 147: 197-217.

Nejstgaard, J.C., B.H. Hansen, L.-J. Naustvoll and U. Båmstedt. 2001. Zooplankton growth, diet and reproductive success compared in simultaneous diatom- and flagellate-microzooplanktondominated plankton blooms. Mar. Ecol. Prog. Ser. 221: 77-91.

Parsons, T.R., Y. Maita and C.M. Lalli. - 1984. A manual of chemical and biological methods for seawater analysis. Pergamon Press, Oxford.

Peinert, R., B. von Bodungen and V.S. Smetacek. - 1989. Food web structure and loss rate. In: W.H. Berger, V.S. Smetacek and G. Wefer (eds.), Productivity of the ocean: present and past, pp. 35-48. John Wiley \& Sons Limited.

Ratkova, T.N., P. Wassmann, P.G. Verity and I.J. Andreassen. 1999. Abundance and biomass of pico-, nano- and microplankton along a transect on Nordvestbanken, north Norwegian shelf, in 1994. Sarsia., 84: 213-225.

Reigstad, M., P. Wassmann, T. Ratkova, E. Arashkevich, A. Pasternak and S. Øygarden. - 2000. Comparison of the springtime vertical export of biogenic matter in three northern Norwegian fjords. Mar. Ecol. Prog. Ser., 201: 73-89.

Richerson, P., R. Armstrong and C.R. Goldman. - 1970. Contemporaneous disequilibrium, a new hypothesis to explain the "paradox of the plankton". Proc. Natl. Acad. Sci. USA., 67: 1710-1714.

Riegman, R., A.A.M. Noordeloos, L. De-Senerpont-Domis and M De-Boer. - 1997. Phytoplankton competition (BEON-GARDEN project). Annu. Rep. Neth. Inst. Sea Res.

Rousseau, V., S. Mathot and C. Lancelot. - 1990. Calculating carbon biomass of Phaeocystis sp. from microscopic observations. Mar. Biol., 107: 305-314.

Sellner, K.G., P. Sawangwong, R. Dawson, W.R. Boynton, W.M. Kemp and J.H. Garber. - 1993. Fate of dinoflagellates in Chesapeake Bay: Is sedimentation likely? In: T.J. Smayda and
Y. Shimizu (eds.), Toxic phytoplankton blooms in the sea. Elsevier Science Publishers B.V.

Smayda, T.J. - 1978. From phytoplankters to biovolume. In: A. Sournia (ed.) Phytoplankton manual, pp. 273-279. Unesco Publications, Paris

Sommer, U. - 1984. The paradox of the plankton: Fluctuations of phosphorus availability maintain diversity of phytoplankton in flow-through cultures. Limnol. Oceanogr., 29: 633-636.

Sommer, U. - 1989. The role of competition for resources in phytoplankton succession. In: U. Sommer (ed.) Plankton ecology, pp. 57-107. Springer Verlag, Berlin, New York.

Sommer, U. - 1994. Are marine diatoms favoured by high Si:N ratios? Mar. Ecol. Prog. Ser. 115: 309-315.

Steemann Nielsen, E. - 1952. The use of radioactive $\left({ }^{14} \mathrm{C}\right)$ for measuring organic production in the sea. J. Cons. int. Explor. Mer., 18: $117-140$.

Steidinger, K.A. and K. Tangen. - 1997. Dinoflagellates. In: C.R. Tomas (ed.) Identifying marine phytoplankton. Academic Press, Harcourt Brace \& Company, New York.

Strathmann, R.R. - 1967. Estimating the organic carbon content of phytoplankton from cell volume or plasma volume. Limnol. Oceanogr., 12: 411-418.

Svensen, C., J.K. Egge and J.E. Stiansen. - 2001. Can silicate and turbulence regulate the vertical flux of biogenic matter? A mesocosm study. Mar. Ecol. Prog. Ser., 217: 67-80.

Thingstad, F. and E. Sakshaug. - 1990. Control of phytoplankton growth in nutrient recycling ecosystems. Theory and terminology. Mar. Ecol. Prog. Ser. 63: 261-272.

Turner J.T., A. Ianora, A. Miralto, M. Laabir and F. Esposito. 2001. Decoupling of copepod grazing rates, fecundity and egghatching success on mixed and alternating diatom and dinoflagellate diets. Mar. Ecol. Prog. Ser. 220: 187-199.

Turpin, D.H. and P.J. Harrison. - 1979. Limiting nutrient patchiness and its role in phytoplankton ecology. J. exp. mar. Biol. Ecol., 39: 151-166.

Wassmann, P. - 1990. Relationship between primary and export production in the boreal coastal zone of the North Atlantic. Limnol. Oceanogr., 35: 464-471.

Wassmann, P. - 1991. Dynamics of primary production and sedimentation in shallow fjords and polls of western Norway. Oceanogr. Mar. Biol. Annu. Rev., 29: 87-154.

Widdows, J. - 1991. Physiological ecology of mussel larvae. Aquaculture., 94: 147-163.

Scient. ed.: M. Alcaraz 